\title{
Analysis of Genetic Diversity in 73 Kentucky Bluegrass Materials by SSR and SRAP Markers
}

\author{
Xiaojun $\mathrm{YUAN}^{1 *}$, Mingyue $\mathrm{TU}^{1}$, Yali $\mathrm{HE}^{2}$, Weiqian $\mathrm{WANG}^{3}$, \\ Jun $\mathrm{LI}^{4}$, Shumin $\mathrm{ZHOU}^{1 *}$ \\ IShanghai University, School of Life Science, Shanghai 200444; Shanghai University, Shanghai Key Laboratory of Bio-Energy Crops, China; \\ yuanxiajun@shu.edu.cn ("correspondingauthor);m18817510336@163.com; zsm79@shu.edu.cn ("correspondingauthor) \\ ${ }^{2}$ Shanghai Jiaotong University, School of Agriculture and Biology, Shanghai 200240, China; heyali@sjtu.edu.cn \\ ${ }^{3}$ Saitama University, Graduate School of Science and Engineering, 255 Shimo-Okubo, Sakura-ku, Saitama City, Saitama 338-8570, \\ Japan;wang.w.232@ms.saitama-u.ac.jp \\ ${ }^{4}$ Shanghai Academy of Agricultural Sciences, Shanghai 201403,China; 18918505087@163.com
}

\begin{abstract}
Kentucky bluegrass (Poa pratensis L.) (KBG) is a commonly used grass that possesses excellent quality, as well as a complex genetic background and reproductive patterns. In this study, a total of $73 \mathrm{KBG}$ germplasms were collected, of which 49 were imported varieties, 5 were Chinese breeding varieties, and 19 were wild materials. A total of 70 simple sequence repeat (SSR) and 75 sequence-related amplification polymorphism (SRAP) markers were selected to use for genetic diversity analysis. From these studies, high levels of polymorphisms were observed in SRAPs (91.8\%) and SSRs (94.5\%), respectively. Three dendrograms that were generated from SRAP, SSR, and SRAP+SSR combined data revealed a general similarity for the positioning of the majority of materials. However, certain materials, including Z65, Z25, and Z27, were found to be located in diverse clusters among different dendrograms. Further analysis demonstrated no significant association between geographical origin and molecular marker clusters in the wild materials. Combined with the seedling phenotype identification carried out in our prior study, it seems as though there is no significant relationship between agronomic characterization and marker-based clustering in these materials, except for in the case of leaf color. These studies provided an increased understanding of genetic diversity among KBG materials, which will be beneficial for genetic improvement and germplasm conservation in the future.
\end{abstract}

Keywords: cluster analysis; genetic resources; molecular markers; Poa pratensis L.; turfgrass

\section{Introduction}

Kentucky bluegrass (Poa pratensis L.) (KBG) is a forage crop native to Asia and Europe, and is one of the most widely used cool-season turfgrass in both temperate and cooler regions (Gan et al., 2016). KBG is able to reproduce both sexually (seeds) and asexually (apomixes), and it has been demonstrated that a complex series of polyploidy and aneuploidy exists among the different strains (Muntzing, 1940; Löve, 1952; Huff, 2003). Both the variable ploidy and the versatile reproduction mode are likely results of its advanced adaptiveness (Raggi et al., 2015). Over a long-term natural selection period in a wide area that is subject to great climatic variation, wild KBG genotypes have been shown to have an increased inherent diversity (Burt and Christians, 1990). With ecotype selection and intraspecific hybridization breeding, an increasing number of KBG cultivars have begun to appear on the commercial turf market (Curley and Jung, 2004).
Typically, morphological traits, disease resistance, and stress tolerance are used to distinguish KBG varieties. These KBG varieties include those with different plant height, panicle height, tillers, flag leaf dimensions, rhizome spread, length (Nittler and Kenny, 1976; Bonos et al., 2000; Shortell et al., 2009), winter color and dormancy, tolerance to and recovery from summer stress, resistance to leaf spot diseases, resistance to stripe smut disease, and other properties (Bara et al., 1993; Murphy et al., 1997). In addition, identification of protein polymorphisms was also used in cultivar classification, including differences in leaf protein, seed protein, isoenzyme, and other properties (Wilkinson and Beard, 1972; Wehner et al., 1976; Wu et al., 1984; Tamkoc and Arslan, 2010). However, with an increased number of KBG varieties, relying only on phenotypic traits and protein markers has made the discrimination of different materials increasingly difficult.

Developments in PCR technology and molecular markers have enabled the generation of a more efficient instrument for the assessment of genetic diversity in numerous plants. Compared with phenotypic traits and 
328

protein characterization methods, molecular markers possess clear advantages (Lombard et al., 2000), including a short test time, easy operation, an environmentally independent method, and sufficient (infinite) numbers, in theory. Currently, different types of molecular markers have been used widely in turfgrass genetic diversity studies. In the case of KBG, random amplification of polymorphic DNA (RAPD) (Johnson et al., 2002; Curley and Jung, 2004; Liang et al., 2009; Fard et al., 2012; Szenejko and Rogalski, 2015; Yuan et al., 2015; Szenejko et al., 2016), amplified fragment length polymorphism (AFLP) (Treuren, 2008), simple sequence repeat (SSR) (Honig et al., 2010; Honig et al., 2012; Raggi et al., 2015), inter-simple sequence repeat (ISSR) (Goldman, 2008; Szenejko et al., 2016), and sequence-related amplified polymorphism (SRAP) (Yuan $e t$ al., 2015) were all utilized to assess the genetic variability present and to identify germplasms.

Microsatellite loci are defined as short tandem repeats of 2 to 6 bp core sequences that are widely distributed throughout eukaryotic genomes in both protein-coding and non-coding regions (Morgante et al., 2002). SSR markers are advantageous in that they are multi-allelic, co-dominant, reliable, abundant in genomes, and contain high numbers of polymorphisms. While SSR marker development requires time and cost, up until now, numerous SSR markers have been reported to be present in forage and turfgrass, including perennial ryegrass (Lolium perenne L.) (Jones et al., 2001; Gill et al., 2006), Italian ryegrass (Lolium multiflorum Lam.) (Hirata et al., 2000; Hirata et al., 2006), white clover (Trifolium repens L.) (Kölliker et al., 2001; Barrett et al., 2004), tall fescue (Festuca arundinacea Schreb.) (Saha et al., 2004; Saha et al., 2006), timothy (Phleum pratense L.) (Cai et al., 2003), zoysiagrass (Zoysia spp.) (Cai et al., 2005), bentgrass (Agrostis) (Kubik et al., 2011; Honig et al., 2016), switchgrass (Panicum virgatum L.) (Tobias et al., 2006; Wang et al., 2011), seashore paspalum (Paspalum vaginatum Swartz) (Harris-Shultz et al., 2013), and KBG (Honig et al., 2010).

The SRAP marker system was first reported by $\mathrm{Li}$ and Quiros in Brassica oleracea, and was aimed to be used for the amplification of open reading frames (ORFs) ( $\mathrm{Li}$ and Quiros, 2001). The CCGG sequence is used in the forward primers to preferentially amplify exons to ORF regions. However, because exonic sequences are typically conserved, the number of polymorphisms amplified with these primers is low across different individuals (Quiros et al., 2001). Reverse primers are designed with the AATT sequence to target AT-rich regions, which are more frequently present in promoters, introns, and spacers (Lin et al., 1999). Because spacers, promoters, and introns are variable, polymorphic bands could be generated across different individuals using different primer combinations. This marker technique is advantageous due to the simplicity, reliability, highly polymorphic, and more informative properties of the technique.

SSRs and SRAPs are powerful techniques that have been used widely for linkage map construction (Jones et al., 2002; Cai et al., 2005; Saha et al., 2005; Xie et al., 2010) and gene tagging (Zhou et al., 2011; Lou et al., 2015; Sun et al., 2015) in turfgrass. These techniques have also been applied for numerous types of genetic polymorphism analyses in turfgrass. Budak et al. (2004b) used 34 SRAP markers to study the genetic diversity and phenetic relationships in 53 buffalograss [Buchloe dactyloides (Nutt.) Engelm.] germplasms. In addition, they also analyzed the relationships of $21 \mathrm{cool}$ and warm-season turfgrasses, as well as other Gramineae species, using 19 SRAP markers (Budak et al., 2004a). For the analysis of orchardgrass (Dactylis glomerata L.), a total of 60 accessions from four continents were studied using 21 SRAP primer pairs (Zeng et al., 2008). Using 11 SRAP primer combinations, the levels of genetic diversity in 56 centipedegrass [Eremochloa ophiuroides (Munro) Hack.] accessions were compared (Milla-Lewis et al., 2012). In the case of KBG, a total of 247 cultivars, experimental selections, and collections were genotyped using 25 SSR markers (Honig et al., 2012), and a total of 11 nuclear and 2 chloroplast SSR markers were used to study the genetic diversity of $33 \mathrm{P}$. pratensis accessions from 23 different countries (Raggi et al., 2015). A total of 80 SSR markers were used to assess genetic relationships between 18 Paspalum accessions (Harris-Shultz et al., 2013). Recently, an assessment of genetic relationships among 74 Agrostis cultivars and accessions were carried out using 23 nuSSR markers (Honig et al., 2016). An overview of the diversity and genetic relationships among 59 accessions of 32 species of the Festuca-Lolium complex were achieved using 22 SRAP primer combinations (Cheng et al., 2016).

In China, the import of turfgrass varieties has recently grown exponentially with every year, with the majority of these varieties introduced from Europe and the United States. In addition, there are several new varieties that were bred domestically, including 'Daqignhsan', 'Huhe' (He et al., 2009), 'Qinghai' (Wang et al., 2010), 'KBG03', and 'KBG04' (Yuan et al., 2014). In this study, we have used SSR and SRAP markers to investigate the genetic diversity of $73 \mathrm{KBG}$ materials from both China and abroad. These 73 materials include different varieties, breeding lines, and wild materials. The objectives of this study were to (i) investigate whether different types of molecular markers generate similar clustering results, and (ii) assess the correlation between marker-based grouping and geographical origin in wild materials.

\section{Materials and Methods}

\section{Plantmaterials}

For this study, a total of $73 \mathrm{KBG}$ materials (Z1-Z73) were collected (Table 1), which included 49 imported varieties, 10 wild materials obtained abroad, 5 domestic varieties/lines, and 9 domestic wild materials (from Jilin, Gansu, Sichuan, and Guizhou provinces in China). Among these, a total of 45 materials (Z27, Z43-Z71) were provided by the State Medium-term Repository for Grass Germplasms in China. In October 2015, 100 grains of each material were sown in $10 \times 10 \times 10 \mathrm{~cm}$ plastic pots. Following one month, a total of 36 seedlings of each type of material were randomly selected and transplanted to potted trays. Plants were watered every other day and were treated with full-strength Hoagland nutrient solution once a month (Hoagland and Arnon, 1950). The entire cultivation process was carried out in a greenhouse at the School of Agriculture and Biology, Shanghai Jiao Tong University, Shanghai, China under natural conditions $\left(15-30{ }^{\circ} \mathrm{C}\right.$ temperature, $40-80 \%$ humidity, and natural sunlight). 
Table 1. Names, types and sources of 73 Kentucky bluegrass materials

\begin{tabular}{|c|c|c|c|c|c|}
\hline Code & $\begin{array}{l}\text { Commercial name or } \\
\text { place of origin }\end{array}$ & Types, Source* & Code & $\begin{array}{l}\text { Commercial name or } \\
\text { place of origin }\end{array}$ & Types, Source* \\
\hline $\mathrm{Z} 01$ & Odyssey & Imported varieties, Bright & $\mathrm{Z} 38$ & Moonnight & Imported varieties, Clover \\
\hline $\mathrm{Z} 02$ & 3 Freedom III & Imported varieties, Bright & Z39 & Right & Imported varieties, Clover \\
\hline $\mathrm{Z} 03$ & Everest & Imported varieties, Bright & $\mathrm{Z} 40$ & 4-season & Imported varieties, Clover \\
\hline $\mathrm{Z} 04$ & Arcadia & Imported varieties, Bright & $\mathrm{Z} 41$ & bright & Imported varieties, Bright \\
\hline Z05 & Nuglade & Imported varieties, Bright & $\mathrm{Z} 42$ & Zahe & Domestic varieties, SABS SJTU \\
\hline Z06 & Award & Imported varieties, Bright & Z43 & Nublue & Imported varieties, Bright \\
\hline $\mathrm{Z} 07$ & Nassau & Imported varieties, Bright & Z44 & $\begin{array}{l}\text { Tianzhu of Gansu } \\
\text { Province1 }\end{array}$ & Domestic wild materials, SMTRGG \\
\hline $\mathrm{Z} 08$ & Classic & Imported varieties, Bright & $\mathrm{Z} 45$ & $\begin{array}{l}\text { Tianzhu of Gansu } \\
\text { Province } 2\end{array}$ & Domestic wild materials, SMTRGG \\
\hline $\mathrm{Z} 09$ & Blue Chip & Imported varieties, Bright & Z46 & $\begin{array}{l}\text { Qibian of Qinghai } \\
\text { Province }\end{array}$ & Domestic wild materials, SMTRGG \\
\hline $\mathrm{Z} 10$ & Kingdom & Imported varieties, Bright & $\mathrm{Z} 47$ & $\begin{array}{l}\text { Tianzhu of Gansu } \\
\text { Province } 3\end{array}$ & Domestic wild materials, SMTRGG \\
\hline $\mathrm{Z} 11$ & Barrister & Imported varieties, Barenbrug, China & $\mathrm{Z} 48$ & Midnight 2 & Imported varieties, Clover \\
\hline $\mathrm{Z} 12$ & Baron & Imported varieties, Barenbrug, China & Z49 & Brilliant & Imported varieties, Clover \\
\hline $\mathrm{Z} 13$ & Merit & Imported varieties, Barenbrug, China & $\mathrm{Z} 50$ & Merit & Imported varieties, Clover \\
\hline $\mathrm{Z} 14$ & Barvictor & Imported varieties, Barenbrug, China & $\mathrm{Z} 51$ & Kenblue & Imported varieties, Clover \\
\hline $\mathrm{Z} 15$ & Midnight & Imported varieties, Clover & $\mathrm{Z} 52$ & Miracle & Imported varieties, Clover \\
\hline $\mathrm{Z} 16$ & Rugby2 & Imported varieties, Clover & $\mathrm{Z} 53$ & Numerit & Imported varieties, Clover \\
\hline $\mathrm{Z} 17$ & Abbey & Imported varieties, Clover & $\mathrm{Z} 54$ & CPP811 (Danmark) & Imported varieties, Clover \\
\hline $\mathrm{Z} 18$ & Sapphire & Imported varieties, Clover & Z55 & CPP812 (Danmark) & Imported varieties, Clover \\
\hline Z19 & Blue fox & Imported varieties, Clover & $\mathrm{Z} 56$ & Allure & Imported varieties, Clover \\
\hline $\mathrm{Z} 20$ & Park & Imported varieties, Clover & $\mathrm{Z} 57$ & Harmony & Imported varieties, Clover \\
\hline $\mathrm{Z} 21$ & Kentucky & Imported varieties, TopGreen & $\mathrm{Z} 58$ & $\begin{array}{c}\text { Dushan of Guizhou } \\
\text { Province }\end{array}$ & Domestic wild materials, SMTRGG \\
\hline $\mathrm{Z} 22$ & Brooklawn & Imported varieties, TopGreen & Z59 & Daqingshan & Domestic varieties, SMTRGG \\
\hline $\mathrm{Z} 23$ & Bedazzled & Imported varieties, TopGreen & $\mathrm{Z} 60$ & Qinghai Province & Domestic wild materials, SMTRGG \\
\hline $\mathrm{Z} 24$ & Nublue & Imported varieties, TopGreen & $\mathrm{Z} 61$ & $\begin{array}{l}\text { Changling of Jilin } \\
\text { Province }\end{array}$ & Domestic wild materials, SMTRGG \\
\hline $\mathrm{Z} 25$ & Avalanche & Imported varieties, Bright & $\mathrm{Z} 62$ & Russia & Wild materials abroad, SMTRGG \\
\hline $\mathrm{Z} 26$ & Huhe 2 & Domestic varieties, SJTU & $\mathrm{Z} 63$ & Russia & Wild materials abroad, SMTRGG \\
\hline $\mathrm{Z} 27$ & $\begin{array}{c}\text { Jilin City of Liaoning } \\
\text { Province }\end{array}$ & Domestic wild materials, SMTRGG & Z64 & Kazakhstan & Wild materials abroad, SMTRGG \\
\hline $\mathrm{Z} 28$ & KBG04 & Domestic varieties, SABS SJTU & $\mathrm{Z} 65$ & Kazakhstan & Wild materials abroad, SMTRGG \\
\hline $\mathrm{Z} 29$ & KBG03 & Domestic varieties, SABS SJTU & Z66 & Kazakhstan & Wild materials abroad, SMTRGG \\
\hline $\mathrm{Z} 30$ & Evergreen & Imported varieties, TopGreen & $\mathrm{Z} 67$ & Russia & $\begin{array}{l}\text { Wild materials abroad, } \\
\text { SMTRGGSMTRGG }\end{array}$ \\
\hline $\mathrm{Z} 31$ & Nu destiny & Imported varieties, TopGreen & $\mathrm{Z} 68$ & Kazakhstan & Wild materials abroad, SMTRGG \\
\hline $\mathrm{Z} 32$ & Superglade & Imported varieties, Bright & Z69 & Russia & Wild materials abroad, SMTRGG \\
\hline $\mathrm{Z} 33$ & Blueberry & Imported varieties, TopGreen & $\mathrm{Z70}$ & the United States & Wild materials abroad, SMTRGG \\
\hline $\mathrm{Z} 34$ & Gourment Midnight & Imported varieties, TopGreen & $\mathrm{Z} 71$ & Russia & Wild materials abroad, SMTRGG \\
\hline $\mathrm{Z} 35$ & B6 & Imported varieties, Barenbrug, China & $\mathrm{Z} 72$ & Ninglan & Domestic wild materials, NXU \\
\hline $\mathrm{Z} 36$ & Jumpstart & Imported varieties, Barenbrug, China & $\mathrm{Z73}$ & Langra & Imported varieties, Bright \\
\hline $\mathrm{Z} 37$ & Liberator & Imported varieties, Clover & & & \\
\hline
\end{tabular}

"Imported varieties were distributed by: Bright, Beijing Bright Turf \& Forage Co., Ltd.; Barenbrug China, Beijing Barenbrug International Co., Ltd.; Clover, Beijing Clover Turf \& Forage Co., Ltd. and TopGreen, Beijing TopGreen Seed Co., Ltd. Domestic cultivars were distributed by: SABS SJTU, School of Agriculture and Biology Science of Shanghai Jiaotong University; SMTRGG, State Medium-term Repository for Grass Germplasms and NXU, Ningxia University. 
DNA extraction and molecular marker polymorphism screening

Identical amounts of fresh leaves were collected from 10 individual plants per germplasm. Leaves were frozen for the subsequent genomic DNA extraction using the CTAB method (Clark, 1997). Extracted DNA samples were visualized on $1.0 \%$ agarose gels via electrophoresis. Extracted DNA was diluted to $40 \mathrm{ng} \mu \mathrm{L}^{-1}$ for PCR reactions. A total of 70 SRAP and 75 SSR primer pairs were used to screen polymorphisms, which were selected from a total of 100 SRAP primer pairs (forward: me1-me10, reverse: em1em10) (Yuan et al., 2015) and 88 SSR primer pairs (Honig et al., 2010), respectively. Primer pairs were prescreened on six genotypes (Z15, Z25, Z28, Z29, Z30 and Z73) in order to identify primers that generated clear bands for further amplification reactions for the total 73 materials. All primers were synthesized by Sangon Biological Engineering Technology and Service Co. Ltd, Shanghai.

SSR and SRAP PCR reactions were carried out in a 10$\mu \mathrm{L}$ mixture: 0.3 unit of Taq DNA polymerase (TaKaRa, Talien, China), $1 \times$ Taq Buffer, $1.5 \mathrm{mmol} \mathrm{L}{ }^{-1} \mathrm{MgCl}_{2}, 100$ $\mu \mathrm{mol} \mathrm{L}{ }^{-1} \mathrm{dNTP}$ mixture, $10 \mathrm{pmol}$ of each primer, and 50ng genomic DNA. The SSR PCR reaction was carried out as follows: $94{ }^{\circ} \mathrm{C}$ for $3 \mathrm{~min}$ for the initial denaturing step, followed by 30 cycles at $94^{\circ} \mathrm{C}$ for $10 \mathrm{~s}, 55^{\circ} \mathrm{C}$ for $30 \mathrm{~s}$, and $72{ }^{\circ} \mathrm{C}$ for $45 \mathrm{~s}$ for denaturing, annealing, and extension, respectively. The annealing temperature was then reduced to $53^{\circ} \mathrm{C}$ for another 15 cycles, followed by a final extension step at $72{ }^{\circ} \mathrm{C}$ for $8 \mathrm{~min}$. The SRAP PCR reaction was carried out as follows: $94{ }^{\circ} \mathrm{C}$ for $3 \mathrm{~min}$ for the initial denaturing step, followed by 8 cycles at $94^{\circ} \mathrm{C}$ for $10 \mathrm{~s}, 37^{\circ} \mathrm{C}$ for $30 \mathrm{~s}$ and $72{ }^{\circ} \mathrm{C}$ for $45 \mathrm{~s}$ for denaturing, annealing, and extension, respectively. The annealing temperature was then increased to $53{ }^{\circ} \mathrm{C}$ for another 35 cycles, followed by a final extension step at $72{ }^{\circ} \mathrm{C}$ for $6 \mathrm{~min}$. The SSR and SRAP products were separated on $6 \%$ and $4 \%$ denatured polyacrylamide gels, respectively. DNA bands were visualized using $\mathrm{AgNO}_{3}$ solution (Bassam et al., 1991). All $\mathrm{PCR}$ reactions were confirmed at least twice.

\section{Statistical analysis}

Genetic relationships between the 73 KBG genotypes were studied using the bands amplified by SSR and SRAP primer pairs. Steady and clear polymorphic loci in each material were used for analysis, and the banding phenotypes were scored as band presence (1) or absence (0). Data were analyzed using the Numerical Taxonomy and Multivariate Analysis System (NTSYSpc) version 2.10 (Exeter Software, Setauket, NY). Genetic similarities between genotypes were calculated using the simple matching coefficient, and a dendrogram was generated based on the unweighted pair group method with the arithmetic average (UPGMA).

\section{Results}

\section{Amplification of SSRs and SRAPs}

Among the 73 different KBG materials, 70 SSR and 75 SRAP primer pairs were tested for the polymorphic bands (Fig. 1, Fig. 2). A total of 1,137 bands were amplified by SSRs, in which 1,075 were found to be polymorphic (94.5\%). Each primer pair generated between 10 and 36 clear bands, with an average number of 18.6 bands. A total of 1,526 bands were detected by SRAPs, of which 1,401 were found to be polymorphic, accounting for $91.8 \%$. The number of fragments amplified by each SRAP primer combination ranged between 4 and 42 (20.3 bands per primer pair). Among these, a total of 595 reproducible and unambiguous bands (233 SSRs and 362 SRAPs) were selected for further genetic diversity analysis.

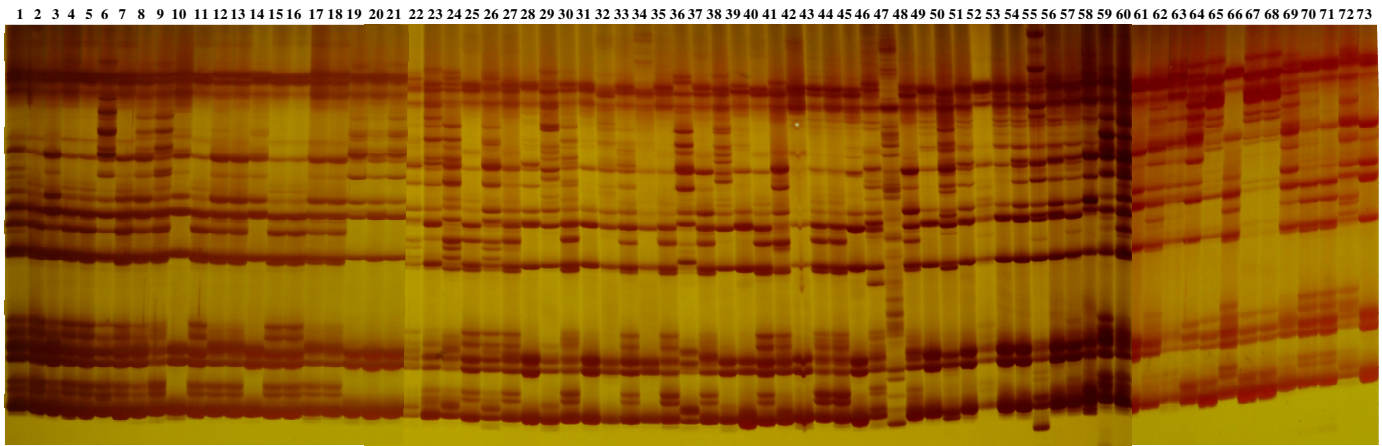

Fig. 1. Amplification bands of 73 Kentucky bluegrass materials by SSR primer pairs (GA403)

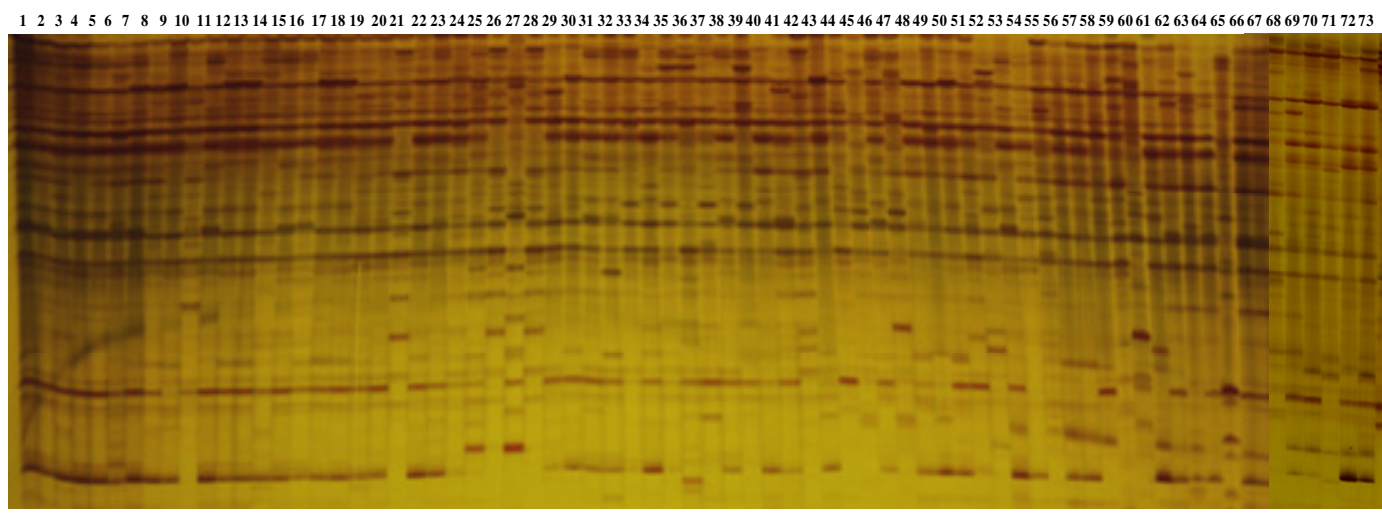

Fig. 2. Amplification bands of 73 Kentucky bluegrass materials by SRAP primer pairs $($ me10 $\times$ em9) 


\section{SSR cluster analysis}

Dendrogram analysis of the SSR data is depicted in Fig. 3. At the genetic similarity coefficient of 0.6 , the 73 materials could be divided into three main clusters, denoted as Cluster I (SSR-I), Cluster II (SSR-II) and Cluster III (SSR-III). SSR-I comprised 46 materials, which accounted for $63 \%$ of the total material. With the exception of four domestic wild materials (Z27, Z46, Z61, and Z72), all others were found to belong to imported commercial cultivars. SSR-II was found to contain nine materials, including three domestic wild materials and one wild material from abroad, covering all domestic varieties/lines (Z26, Z28, Z29, Z42, and Z59). These results demonstrated that these five Chinese breeding lines were of close genetic relationship. SSR-III covered 18 materials, including 7 imported varieties, 2 domestic wild materials, and nearly all of the foreign wild materials.

\section{SRAP cluster analysis}

A dendrogram that was based on SRAPs divided all of the materials into two main clusters at a similarity level of 0.53 (Fig. 4). The first cluster included a total of 63 materials grouped together, which was comprised of all of the imported varieties (49) and the majority of the domestic and abroad wild materials (14). All domestic varieties/lines, three domestic wild materials, and two foreign wild materials were compiled into the second cluster (SRAP-II). Materials within the first cluster were grouped into two further subclusters at the similarity level of 0.62 . The SRAP-

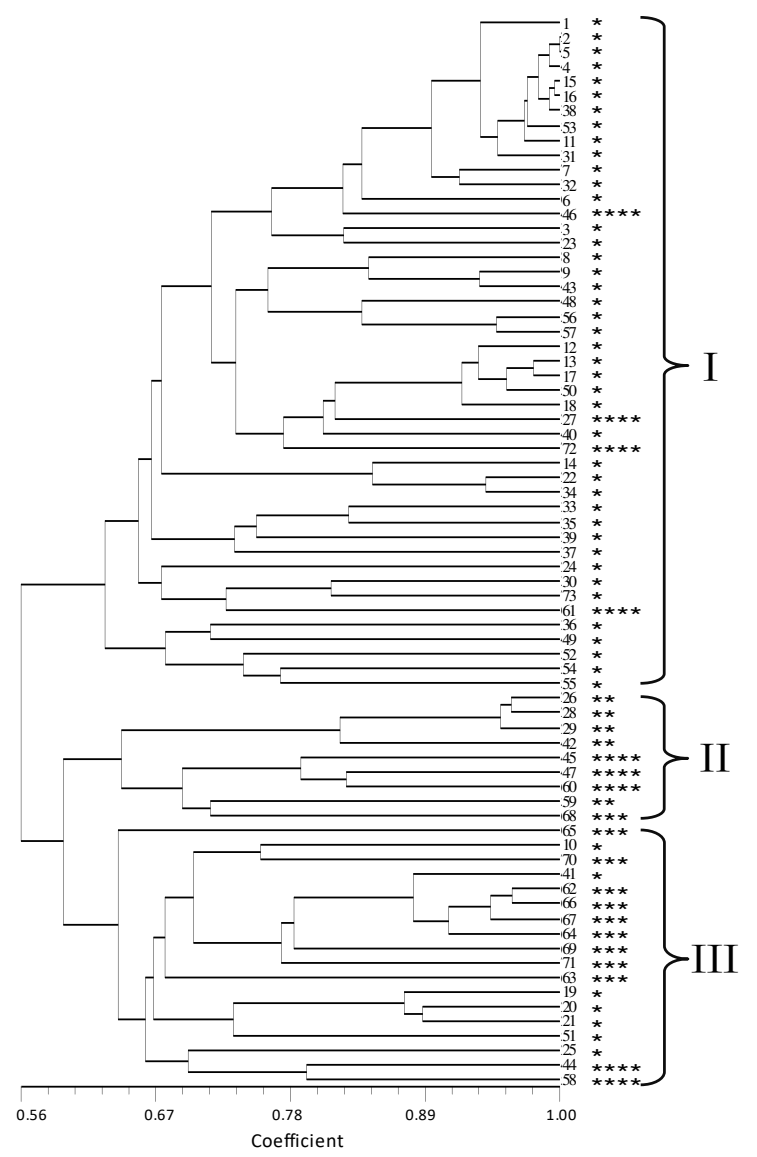

Fig. 3. UPGMA cluster analysis based on 233 SSRs of 73 Kentucky bluegrass materials; *: Imported varieties; ${ }^{* *}$ : Domestic varieties; ${ }^{* * *}$ : Wild materials abroad; ${ }^{* * * *}$ : Domestic wild materials
III subcluster contained only one domestic wild material (Z27), while the SRAP-I subcluster comprised the remaining materials. SRAP-I, SRAP-II, and SRAP-III represented Cluster I, Cluster II, and Cluster III, respectively, in the SRAP dendrogram.

\section{Cluster analysis of combined SSR and SRAP data}

In addition, SSR and SRAP data were combined for UPGMA cluster analysis (Fig. 5). With this analysis, two major clusters were observed in the dendrogram at the genetic similarity coefficient of 0.54 . The second major cluster was found to consist of 5 domestic varieties/lines, 2 foreign wild materials, and 3 domestic wild materials. The first major cluster was found to be comprised of the remaining 63 materials. With a higher similarity coefficient (0.63), two subclusters [(SSR+SRAP)-I and (SSR+SRAP)III] were distinguished from the first major cluster. (SSR+SRAP)-I was found to be comprised of 47 materials: 43 of which were imported varieties and 4 of which were domestic wild materials (Z46, Z61, Z72, and Z27). (SSR+SRAP)-III was found to be comprised of a total of 16 materials, which included 2 domestic wild materials, 8 wild materials from abroad, and 6 imported varieties. At a similarity level of 0.63 , the foreign wild material $\mathrm{Z} 65$ [(SSR+SRAP)-IV] was separated from the other 9 materials [(SSR+SRAP)-II] in the second major cluster. (SSR+SRAP)-I, (SSR+SRAP)-II, (SSR+SRAP)-III and (SSR+SRAP)-IV made up Cluster I to IV in the SSR+SRAP dendrogram.

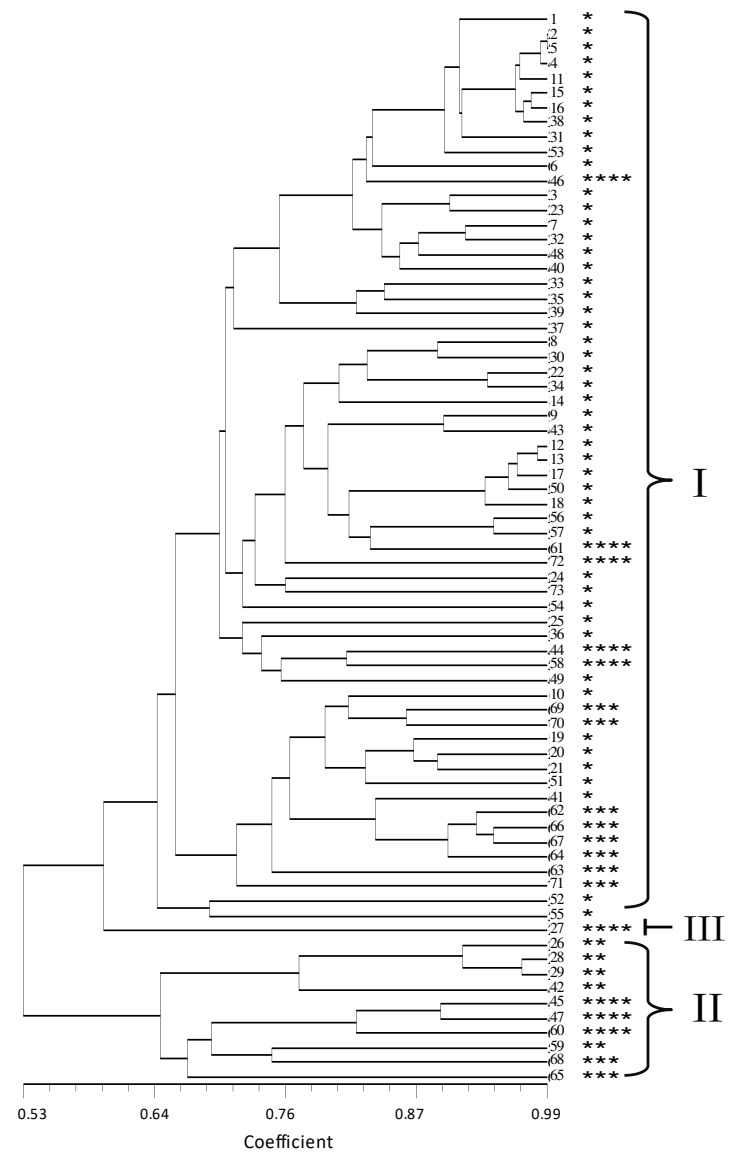

Fig. 4. UPGMA cluster analysis based on 362 SRAPs of 73 Kentucky bluegrass materials; *: Imported varieties; ${ }^{* *}$ : Domestic varieties; ${ }^{* * *}$ : Wild materials abroad; ${ }^{* * * *}$ : Domestic wild materials 


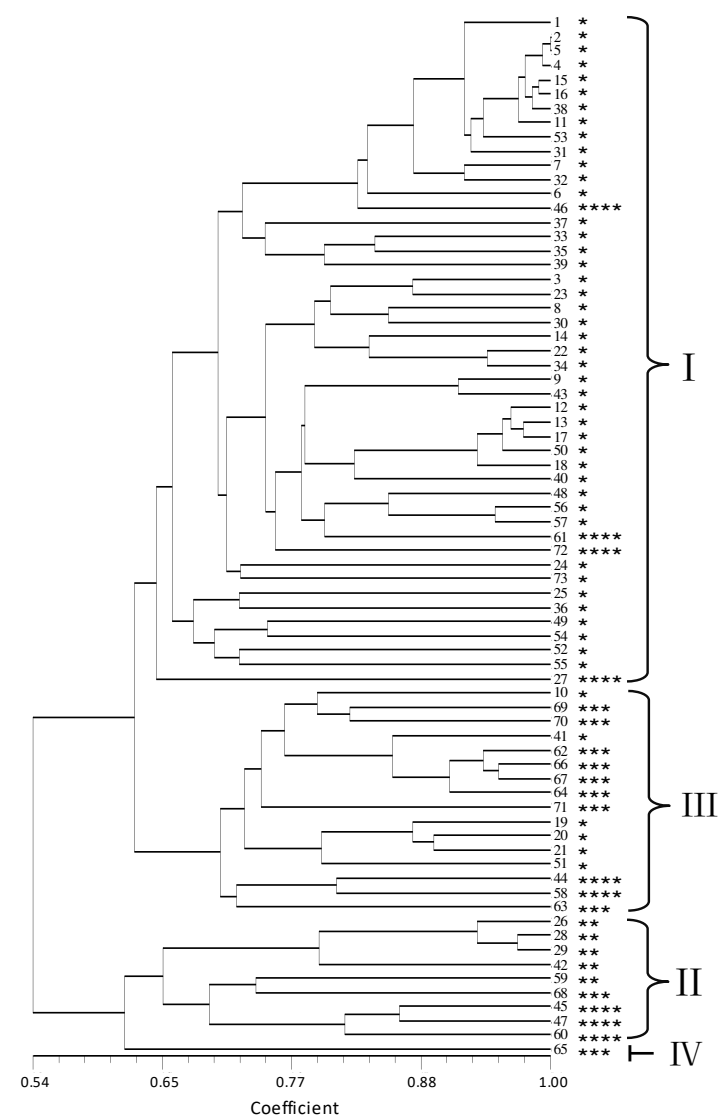

Fig. 5. UPGMA cluster analysis based on 233 SSRs and 362 SRAPs of 73 Kentucky bluegrass materials; *: Imported varieties: ${ }^{* *}$ : Domestic varieties; ${ }^{* *}$ : Wild materials abroad; ${ }^{* * * *}$ : Domestic wild materials

\section{Discussion}

SSRs and SRAPs have been applied to cultivar identification and genetic variation assessment for numerous turfgrass species. In the current study, we used SSR and SRAP markers to analyze relationships among various KBG material sources. Both SRAPs and SSRs were found to have high polymorphism (> 91\%) among the 73 materials. This high level of polymorphisms was similar to that found in other grass studies: $67 \%$ in 8 perennial ryegrass genotypes (101 SSRs) (Jones et al., 2001), 93\% in 8 Cynodon transvaalensis genotypes (544 SSRs) (Tan et al., 2014), 84\% in 60 orchardgrass accessions (21 SRAPs) (Zeng et al., 2008), 95\% in 53 buffalograss germplasms (34 SRAPs) (Budak et al., 2004b), and 100\% in 59 FestucaLolium complex accessions (22 SRAPs) (Cheng et al., 2016). The high number of polymorphisms identified in SSR markers was also observed in two other KBG studies (Honig et al., 2012; Raggi et al., 2015). All of these results demonstrate that SSRs and SRAPs represent ideal molecular markers that can be used for the efficient assessment of genetic diversity and relationships in turfgrass.

While the placement of some materials was different, three dendrograms that were generated from SSR, SRAP, and their combined data demonstrated generally similar results. The majority of materials in (SSR+SRAP)-II were found to correspond to those in SSR-II and SRAP-II. This included 9-10 of the same domestic and foreign wild materials and domestic breeding varieties/lines. In addition, the SSR-I germplasms were also found to be very similar to those in (SSR+SRAP)-I. SRAP-I included both Cluster I and Cluster III of SSR or SSR+SRAP dendrograms. In addition, three domestic wild materials obtained from Jilin (Z61), Qinghai (Z46), and Ningxia (Z72) were always found to be grouped with the majority of the commercial varieties obtained from abroad.

Some materials were located in different clusters within the three dendrograms. For example, the wild material 'Kazakhstan' (Z65) was found to be separated from all other materials in the SSR+SRAP dendrogram. However, it was gathered in SSR-III and SRAP-II, respectively. In addition, the imported variety 'Avalanche' (Z25) was not found in the corresponding clusters between SSR and SSR+SRAP dendrograms. The domestic wild material Z27 (obtained from Jilin Province in China) was grouped in Cluster I in both SSR and SSR+SRAP dendrograms. However, it was separated from all of the others in the SRAP cluster analysis.

In our previous study, we demonstrated that a dendrogram of the same materials (except for Z73) carried out with 20 RAPD primers was generally similar to the results obtained in this study (Tu et al., 2017). Clusters I and III in the RAPD dendrogram were found to approximately correspond to that in the SSR and SSR+SRAP dendrograms. In this study, Cluster II materials were found to be equal to the sum of the materials in Clusters II and IV in the RAPD cluster analysis.

In the case of other species, genetic diversity analyses were also carried out using different types of molecular markers. In melon (Cucumis melo L.), studies have used RAPD and SSR markers to study genetic relationships between different accessions (Staub et al., 2000). In the case of watermelon [Citrullus lanatus (Thunb.) Matsum. \& Nakai], studies have used SRAP, SSR, and SRAP-SSR combined data to estimate genetic diversity (Wang et al., 2015). The dendrograms that were generated from the use of different molecular markers all revealed a high similarity. However, among some Iraqi walnut genotypes (Juglans regia L.), the cluster analysis carried out by RAPD and SSR markers demonstrated a distinct diversity (Salieh et al., 2013). In the case of Monascus, cluster results generated using SRAP and ISSR data were found to share immense similarity, with only minor differences identified in the subgroups (Shao et al., 2011). Differences observed between cluster analyses based on diverse marker types could be caused by the use of different marker systems, different marker amounts, and/or different testing populations. Different molecular markers are developed using different principles, and therefore the position of the amplified fragment on the whole genome as well as the amount of genome coverage is expected to also differ. Within the same species, sampling variation could vary between populations. Therefore, a dendrogram that was constructed by a greater number of types and a greater number of molecular markers would be more realistic, such as the SSR+SRAP dendrogram used in this study.

In Napier grass (Pennisetum purpureum Schum) and bermudagrass (Cynodon dactylon) studies (Babu et al., 2009; Farsani et al., 2011; Li et al., 2011), a correlation was found 
between molecular marker clustering and geographical origin, to some degree. The majority of ecotypes were clustered according to their geographical distribution, and were also reported for KBG (Szenejko et al., 2016). In this study, based on the cluster analysis of SSR+SRAP data, a total of $80 \%$ of wild materials obtained from abroad (8 materials), including from Russia, Kazakhstan, and the United States, were grouped together in Cluster III, while a total of 9 domestic wild materials were distributed among three different clusters. In Cluster I, a total of 4 materials were collected from Qinghai, Jilin, Ningxia, and Liaoning provinces. A total of 2 germplasms in Cluster III were generated separately from Gansu and Guizhou Provinces, and a total of 3 materials in Cluster II were obtained from Gansu and Qinghai Provinces. We observed no obvious relationship between the geographical origin and the molecular marker clusters in the wild KBG materials studied here. This same result was observed in another clustering study in Poa pratensis accessions, representing 26 countries using RAPD markers (Johnson et al., 2002). The reasons for discrepancies could be due to the diffusion of species introduced, introgression through the hybridization of geographically diverse genetic stocks, and a potential inherent genetic overlap that could exist in these accessions.

Numerous studies have demonstrated a significant or partial correlation between RAPD-based grouping and morphological classification in KBG (Huff, 2001; Johnson et al., 2002; Curley and Jung, 2004; Szenejko and Rogalski, 2015). Combined with the seedling phenotype identification carried out in previous work (Tu et al., 2017), we found no significant association between agronomic characterization (plant height, tillers per plant, and leaf width) and marker-based clustering in these materials, with the exception of leaf color. This could be due to differences in experimental materials and morphological characterizations that were used in the different studies. In addition, certain critical agronomic traits typically received greater attention in the breeding program and were also selected in the morphological identification. Thus, some materials with similar phenotypes could possibly vary from their genetic source.

\section{Conclusions}

Both SRAPs and SSRs were found to possess high polymorphisms among the $73 \mathrm{KBG}$ materials used in this study. Three dendrograms generated from SRAP, SSR, and SRAP+SSR combined data demonstrated a general similarity, and some materials studied were found to be placed in different clusters. Further analysis also demonstrated no significant association between the geographical origin and the molecular marker clusters in the wild materials studied. In addition, we observed no significant relationship between the majority of agronomic characterization and marker-based clustering in the materials studied, with the exception of leaf color. These results enable a better understanding of genetic diversity in KBG materials, and could function to facilitate further studies of genetic improvement and germplasm conservation.

\section{Acknowledgements}

This work was supported by the National Natural Science Foundation of China, grant number 31502002.

\section{References}

Babu C, Sundaramoorthi J, Vijayakumar G, Ram SG (2009). Analysis of genetic diversity in Napier grass (Pennisetum purpureum Schum) as detected by RAPD and ISSR markers. Journal of Plant Biochemistry and Biotechnology 18:181-187.

Bara RF, Dickson WK, Murphy JA, Smith DA, Funk CR (1993). Performance of Kentucky bluegrass cultivars and selections in New Jersey turftrials. Rutgers Turfgrass Proceedings 25:49-94.

Barrett B, Griffiths A, Schreiber M, Ellison N, Mercer C, Bouton J, ... Woodfield D (2004). A microsatellite map of white clover. Theoretical and Applied Genetics 109:596-608.

Bassam BJ, Caetano-Anollés G, Gresshoff PM (1991). Fast and sensitive silver staining of DNA in polyacrylamide gels. Analytical Biochemistry 196:80-83.

Bonos SA, Meyer WA, Murphy JA (2000). Classification of Kentucky bluegrass genotypes grown as spaced-plants. HortScience 35(5):910913.

Budak H, Shearman RC, Gaussoin RE, Dweikat I (2004a). Application of sequence-related amplified polymorphism markers for characterization of turfgrass species. HortScience 39(5):955-958.

BudakH, Shearman RC, ParmaksizI, Gaussoin RE, Riordan TP, Dweikat I (2004b). Molecular characterization of buffalograss germplasm using sequence-related amplified polymorphism markers. Theoretical and Applied Genetics 108:328-334.

Burt MG, Christians NE (1990). Morphological and growth characteristics of low- and high-maintenance Kentucky bluegrass cultivars. Crop Science 30:1239-1243.

Cai HW, Inoue M, Yuyama N, Takahashi W, Hirata M, Sasaki T (2005). Isolation, characterization and mapping of simple sequence repeat markers in zoysiagrass (Zoysia spp.). Theoretical and Applied Genetics 112:158-166.

Cai HW, Yuyama N, Tamaki H, Yoshizawa A (2003). Isolation and characterization of simple sequence repeat markers in the hexaploid forage grass timothy (Phleum pratense L.). Theoretical and Applied Genetics 107:1337-1349.

Cheng Y, Ma X, Zhou K, Humphreys MW, Zhang XQ (2016). Phylogenetic analysis of Festuca-Lolium complex using SRAP markers. Genetic Resources and Crop Evolution 63:7-18.

Clark MS (1997). Plant molecular biology: a laboratory manual. SpringerVerlag, Berlin Heidelbergpp 8-9.

Curley J, Jung G (2004). RAPD-based genetic relationships in Kentucky bluegrass: comparison of cultivars, interspecific hybrids, and plant introductions. CropScience 44:1299-1306.

Fard JR, Zamani Z, Moghaddam MRF, Kafi M (2012). Evaluation of genetic diversity among some genotypes of Kentucky bluegrass by RAPD molecular markers. Horticulture, Environment and Biotechnology 53(4):298-303. 
334

Farsani TM, Etemadi N, Sayed-Tabatabaei BE, Talebi M (2011). Assessment of genetic diversity of bermudagrass (Cynodon dactylon) using ISSR markers. International Journal of Molecular Sciences 13:383-392.

Gan L, Di R, Chao YH, Han LB, Chen XW, Wu C, Yin SX (2016).De Novo transcriptome analysis for Kentucky bluegrass dwarf mutants induced by space mutation. PLoS One 11(3),e0151768.

Gill GP, Wilcox PL, Whittaker DJ, Winz RA, Bickerstaff P, Echt CE, ... Gardner RC (2006). A framework linkage map of perennial ryegrass based on SSR markers. Genome 49:354364.

Goldman JJ (2008). The use of ISSR markers to identify Texas bluegrass interspecifichybrids. Plant Breeding 127:644646.

Harris-Shultz K, Raymer P, Scheffler BE, Arias RS (2013). Development and characterization of seashore paspalum SSR markers. Crop Science 53:1-7.

He YL, Chen J, Guo JF, Zhao ZY, Lu X (2009). Breeding of new line 'Huhe' and evaluation of germplasms of Kentucky bluegrass under artificial stresses and natural conditions in Shanghai.Journal of Shanghai Jiaotong University (Agricultural Science) 27:189-195 (in Chinese with English abstract).

Hirata M, Cai HW, Inoue M, Yuyama N, Miura Y, Komatsu T, ... Fujimori M (2006). Development of simple sequence repeat (SSR) markers and construction of an SSR-based linkage map in Italian ryegrass (Lolium multiflorum Lam.). Theoretical and Applied Genetics 113:270-279.

Hirata M, Fujimori M, Komatsu T (2000). Development of simple sequence repeat (SSR) markers in Italian ryegrass. In: Proceedings of the 2nd International Symposium on molecular breeding of forage crops 2000. Victoria, Australiapp 51.

Hoagland CR, Arnon DI (1950). The solution-culture method for growing plants without soil. California Agricultural Experiment Station Circular 347:357-359.

Honig JA, Averello V, Bonos SA, Meyer WA (2012). Classification of Kentucky bluegrass (Poa pratensis L.) cultivars and accessions based on microsatellite (simple sequence repeat) markers. HortScience 47(9):1356-1366.

HonigJA, Bonos SA, Meyer WA (2010). Isolation and characterization of 88 polymorphic microsatellite markers in Kentucky bluegrass (Poa pratensis L.).HortScience 45(11):1759-1763.

HonigJA, Kubik C, Averello V, VaiciunasJ, Meyer WA, Bonos SA (2016). Classification of bentgrass (Agrostis) cultivars and accessions based on microsatellite (SSR) markers. Genetic Resources and CropEvolution 63:1139-1160.

Huff DR (2001). Characterization of Kentucky bluegrass cultivars using RAPD markers. International Turfgrass Society Research Journal 9:169-175.

Huff DR (2003). Kentucky bluegrass. In: Casler MD, Duncan RR (Eds). Turfgrass biology, genetics, and breeding. Wiley, Hoboken, NJ pp 2738.

Johnson RC, Johnston WJ, Golob CT, Nelson MC, Soreng RJ (2002). Characterization of the USDA Poa pratensis collection using RAPD markers and agronomic descriptors. Genetic Resources and Crop Evolution 49:349-361.
Jones ES, Dupal MP, Dumsday JL, Hughes LJ, ForsterJW (2002). An SSRbased genetic linkage map for perennial ryegrass (Lolium perenne $\mathrm{L}$ ). Theoretical and Applied Genetics 105:577-584.

Jones ES, Dupal MP, Kölliker R, Drayton MC, Forster JW (2001). Development and characterisation of simple sequence repeat (SSR) markers for perennial ryegrass (Lolium perenne L.). Theoretical and Applied Genetics 102:405-415.

Kölliker R, Jones ES, Drayton MC, Dupal MP, Forster JW (2001). Development and characterisation of simple sequence repeat (SSR) markers for white clover (Trifolium repens L). Theoretical and Applied Genetics 102:416-424.

Kubik C, Honig J, Bonos SA (2011). Characterization of 215 simple sequence repeat markers in creeping bentgrass (Agrostis stolonifera $\mathrm{L}$ ). Molecular Ecology Resources 11:872-876.

Li G, Quiros CF (2001). Sequence-related amplified polymorphism (SRAP), a new marker system based on a simple PCR reaction: its application to mapping and gene tagging in Brassica. Theoretical and Applied Genetics 103:455-461.

Li HY, Liu L, Lou YH, Hu T, Fu JM (2011). Genetic diversity of Chinese natural bermudagrass (Cymodon dactylon) germplasm using ISSR markers. ScientiaHorticulturae 127:555-561.

Liang M, Gao LN, Chen YJ, Zhang XY (2009). Classification and genetic diversity of Kentucky bluegrasses by using RAPD markers. Journal of Northeast Agricultural University 16(4):9-13.

Lin XY, Kaul S, Rounsley S, Shea TP, Benito MI, ... Venter JC (1999). Sequence and analysis of chromosome 2 of the plant Arabidopsisthalian. Nature 402:761-768.

Lombard V, Baril CP, Dubreuil P, Blouet F, Zhang D (2000). Genetic relationships and fingerprinting of rapeseed cultivars by AFLP: consequences for varietal registration. Crop Science 40:1417-1425.

Lou YH, Hu LX, Chen L, Sun XY, Yang Y, Liu HM, Xu QG (2015). Association analysis of simple sequence repeat (SSR) markers with agronomic traits in tall fescue (Festuca arundinacea Schreb.). PLoS One 10(7), $\mathrm{e} 0133054$.

Löve A (1952). Preparatory studies for breeding Icelandic Poa irrigata. Hereditas 38(1):11-32.

Milla-Lewis SR, Kimball JA, Zuleta MC, Harris-Shultz KR, Schwartz BM, Hanna WW (2012). Use of sequence-related amplified polymorphism (SRAP) markers for comparing levels of genetic diversity in centipedegrass (Eremochloa ophiuroides (Munro) Hack.) germplasm. Genetic Resources and Crop Evolution 59:1517-1526.

Morgante M, Hanafey M, Powell W (2002). Microsatellites are preferentially associated with nonrepetitive DNA in plant genomes. Nature Genetics 30:194200.

Muntzing A (1940). Further studies on apomixis and sexuality in Poa Hereditas 26: 115-188.

Murphy JA, Bonos S, Perdomo P (1997). Classification of Poa pratensis genotypes. International Turfgrass Society Research Journal 8:11761183.

Nittler LW, Kenny TJ (1976). Crown, tiller, and rhizome characteristics of Kentucky bluegrass cultivars. AgronomyJournal 68:395-397.

Quiros CF, Grellet F, Sadowski J, Suzuki T, Li G, Wroblewski T (2001). Arabidopsis and Brassica comparative genomics: sequence, structure and 
gene content in the $A B I 1-R p s 2-C k 1$ chromosomal segment and related regions. Genetics 157:1321-1330.

Raggi L, Bitocchi E, Russi L, Marconi G, Sharbel TF, Veronesi F, Albertini E (2015). Understanding genetic diversity and population structure of a Poa pratensis worldwide collection through morphological, nuclear and chloroplast diversity analysis. PLoS One 10(4),e0124709.

Saha MC, Cooper JD, Mian MAR, Chekhovskiy K, May GD (2006). Tall fescue genomic SSR markers: development and transferability across multiple grass species. Theoretical and Applied Genetics 113:14491458.

Saha MC, Mian MAR, Eujayl I, Zwonitzer JC, WangLJ, May GD (2004). Tall fescue EST-SSR markers with transferability across several grass species. Theoretical and Applied Genetics 109:783-791.

Saha MC, Mian R, Zwonitzer JC, Chekhovskiy K, Hopkins AA (2005). An SSR- and AFLP-based genetic linkage map of tall fescue (Festuca arundinacea Schreb.). Theoretical and Applied Genetics 110:323-336.

Salieh FMH, Tahir NA, FarajJM(2013). Assessment of genetic relationship among some Iraqi walnut genotypes (Juglans regia L.) in Sulaimani region using RAPD and SSR molecular markers. Jordan Journal of Agricultural Sciences 9(3):351-362.

Shao YC, Xu L, Chen FS (2011). Genetic diversity analysis of Monascus strains usingSRAP and ISSR markers. Mycoscience 52:224-233.

Shortell RR, Meyer WA, Bonos SA (2009). Classification and inheritance of morphological and agronomic characteristics in Kentucky bluegrass (Poapratensis L.).HortScience 44(2):274-279.

Staub JE, Danin-Poleg Y, Fazio G, Horejsi T, Reis N, Katzir N (2000). Comparative analysis of cultivated melon groups (Cucumis melo L.) using random amplified polymorphic DNA and simple sequence repeat markers. Euphytica 115:225-241.

Sun XY, Du ZM, Ren J, Amombo E, Hu T, Fu JM (2015). Association of SSR markers with functional traits from heat stress in diverse tall fescue accessions. BMC Plant Biology 15:116.

Szenejko M, Rogalski M (2015). Characterization of morphological traits and RAPD polymorphism in selected forms of Kentuckybluegrass (Poa pratensis L.). Biodiversity Research and Conservation 37:1-10.

Szenejko M, Śmietana P, Stępień E (2016). Genetic diversity of Poa pratensis L. depending on geographical origin and compared with genetic markers. PeerJ 4, e2489.

Tamkoc A, Arslan E (2010). Comparison of agronomic characters, total seed storage proteins and their use for genotypes discrimination in the Kentucky bluegrass (Poa pratensis L.). Biotechnology and Biotechnological Equipment 24(1):1573-1576.

Tan CC, Wu YQ, Taliaferro CM, Bell GE, Martin DL, Smith MW (2014). Development and characterization of genomic SSR markers in Cynodon transvaalensis Burtt-Davy. Molecular Genetics and Genomics 289:523-531.
Tobias CM, Hayden DM, Twigg P, Sarath G (2006). Genic microsatellite markers derived from EST sequences of switchgrass (Panicum virgatum L.). Molecular Ecology Notes 6:185-187.

Treuren RV (2008). AFLP fingerprinting of Kentucky bluegrass (Poa pratensis L.) from undisturbed Dutch grasslands: implications for conservation. Plant Genetic Resources Newsletter 153:1-8.

Tu MY,LiJ, He YL, Li X,Li J, Yuan XJ (2017). Genetic diversity analysis of Kentucky bluegrass cultivars by RAPDs. Acta Prataculturae Sinica 26(7):71-81 (in Chinese with English abstract).

Wang LY, Bi YF, Ma YS, Shi JJ, Ji YJ (2010). Breeding of a new variety Poa pratensis L. cv. Qinghai for tolerance to low temperature. Chinese Journal of Grassland 32(6):16-20 (in Chinese with English abstract).

Wang PQ, Li Q, Hu JB, Su Y (2015). Comparative analysis of genetic diversity among Chinese watermelon germplasms using SSR and SRAP markers, and implications for future genetic improvement. Turkish Journal of Agriculture and Forestry 39:322-331.

Wang YW, Samuels TD, Wu YQ(2011). Development of 1,030 genomic SSR markers in switchgrass. Theoretical and Applied Genetics 122:677686.

Wehner DJ, Duich JM, Watschke TL (1976). Separation of Kentucky bluegrass cultivars using peroxidase isoenzyme banding patterns. Crop Science 16:475-480.

Wilkinson JF, Beard JB (1972). Electrophoretic identification of Agrostis palustris and Poapratensis cultivars. CropScience 12:833-834.

Wu L, Harivandi AH, Harding JA, Davis WB (1984). Identification of Kentucky bluegrass cultivars with esterase and phosphoglucomutase isoenzyme markers. Crop Science 24:763-768.

Xie WG, ZhangXQ, Cai HW, HuangLK, Peng Y,MaX (2010). Genetic maps of SSR and SRAP markers in diploid orchardgrass (Dactylis glomerata L.) using the pseudo-testcross strategy. Genome 54:212-221.

Yuan XJ, Bao ZJ, He YL (2014). Selection of new lines 'KBG03' and 'KBG04' for summer-tolerance and turf quality evaluation of the new lines with 23 other germplasms in Kentucky bluegrass. Journal of Shanghai Jiaotong University (Agricultural Science) 32(3):51-61 (in Chinese with English abstract).

Yuan XJ,HeYL, HuangJ, Wen H,ZhouHH, GaoQY,ZhouSM(2015). Development of a SCAR marker for rapid identification of new Kentucky bluegrass breeding lines. Notulae Botanicae Horti Agrobotanici Cluj-Napoca 43(1):79-85.

ZengB,ZhangXQ,Lan Y, Yang WY (2008). Evaluation of genetic diversity and relationships in orchardgrass (Dactylis glomerata L.) germplasm based on SRAP markers. Canadian Journal of Plant Science 88:53-60.

Zhou YJ, Wang XG, Zhang XQ (2011). Development and application of a SRAP marker for the identification of sex in Buchloe dactyloides. Euphytica 181:261-266. 